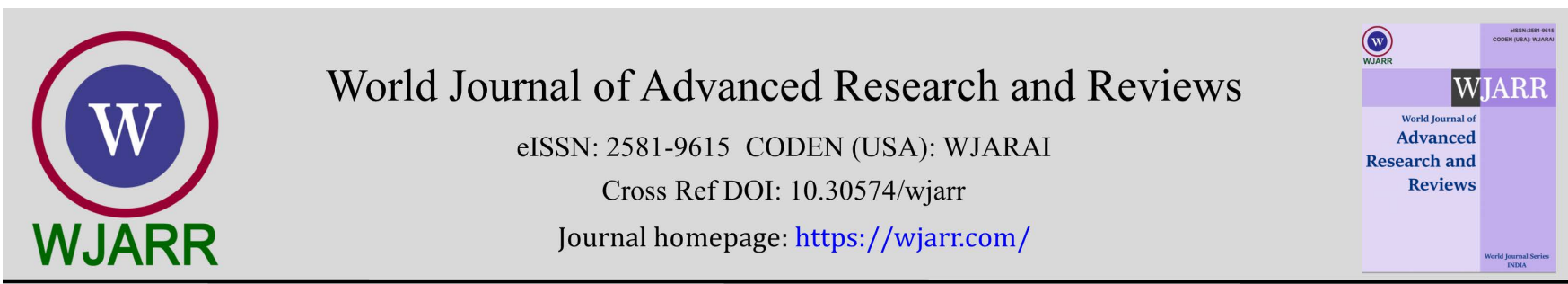

(RESEARCH ARTICLE)

Check for updates

\title{
Assessment of antifungal potentials of violacein extract from Chromobacterium violaceum isolated from domestic and recreational water sources in Owerri, Imo State, Nigeria
}

\author{
Joy Nkeiruka Dike-Ndudim *, Lovelyn Chinyeaka Ugenyi and Chizaram Winners Ndubueze \\ Department of Medical Laboratory Science, Imo State University, Owerri, Imo State, Nigeria.
}

World Journal of Advanced Research and Reviews, 2021, 10(03), 168-172

Publication history: Received on 20 April 2021; revised on 08 June 2021; accepted on 11 June 2021

Article DOI: https://doi.org/10.30574/wjarr.2021.10.3.0243

\begin{abstract}
Anti-Microbial Resistance (AMR) in superficial fungal infections are major worldwide public health problem that affects a large part of the human population globally. The antifungal potentials of violacein extracted from Chromobacterium violaceum isolated from domestic and recreational water sources in Owerri, Imo State, Nigeria, was assessed. Three water samples were collected from different locations of the Otamiri River, five from different swimming pools and three from different borehole locations in Owerri Metropolis. The samples were cultured on nutrient agar by pour plate method. The violet colonies of Chromobacterium violaceum were counted, characterized and identified. Water sample from Otamiri River station-1 had the highest bacteria count $\left(20.00 \times 10^{1} \mathrm{CFU} / \mathrm{Ml}\right.$ and $\left.19.50 \times 10^{1} \mathrm{CFU} / \mathrm{mL}\right)$ respectively. Swimming pool 1 and 3 bacterial counts were $\left(14.50 \times 10^{1} \mathrm{CFU} / \mathrm{mL}, 11.00 \times 10^{1} \mathrm{CFU} / \mathrm{mL}\right.$ and $\left.11.50 \times 10^{1} \mathrm{CFU} / \mathrm{mL}\right)$ respectively. For borehole 1,2 and 3 , swimming pool 2, 4 and 5 counts were $\left(0.00 \times 10^{1} \mathrm{CFU} / \mathrm{mL}\right)$. The ethanolic extracts from the isolates (violacein) and the control drug (fluconazole $50 \mu \mathrm{g} / \mathrm{mL}$ ) both had inhibitory effects on the test organisms (Candida albicans and Aspergillus niger) at different concentrations. The MIC of Fluconazole on Candida albicans and A. niger were $25 \mu \mathrm{g} / \mathrm{ml}$ and $50 \mu \mathrm{g} / \mathrm{Ml}$, respectively. Violacein from both swimming pools and Otamiri River isolates had MIC of $8.75 \mathrm{mg} / \mathrm{ml}$ on A. niger and MIC of $4.375 \mathrm{mg} / \mathrm{ml}$ on Candida albicans. Violacein which proved to have inhibitory effects on Candida albicans and Aspergillus niger can be harnessed for treatment of infections caused by these fungi.
\end{abstract}

Keywords: Antifungal; Water; Antimicrobial Resistance; Chromobacterium violaceum; Aspergillus niger; Candida albicans

\section{Introduction}

Antimicrobial resistance (AMR) in superficial fungal infections are also a major worldwide public health problem that affects more than $30 \%$ of the human population globally [1].

Among these fungal diseases, dermatophytosis, or tinea, is one of the most frequently encountered human fungal infections. Infections caused by T. rubrum species are very difficult to treat and there are very few antifungal drugs available clinically to control this infection [2].

Candida albicans infections are the top source of fungal infections in critically ill or otherwise immunocompromised patients. Once in their life, about $75 \%$ of women will suffer from Vulvo-Vaginal Candidiasis (VVC) and about $90 \%$ of these infections are caused by C. albicans [3].

\footnotetext{
${ }^{*}$ Corresponding author: Joy Nkeiruka Dike-Ndudim

Department of Medical Laboratory Science, Imo State University, Owerri, Imo State, Nigeria.

Copyright $(2021$ Author(s) retain the copyright of this article. This article is published under the terms of the Creative Commons Attribution Liscense 4.0.
} 
Most definitive work in the area of antifungal susceptibility of Aspergillus detected azole resistance. The azole group of antifungal agents such as ketoconazole and fluconazole have been used for the treatment of various fungal infections especially, dermatomycosis. Azoles are synthetic drugs and although effective, but because of increased use, azole resistant pathogens have been reported. Presently, the fungal diseases have become more dangerous, and a number of them become more resistant to many classical clinically used antibiotics [4].

The developments and associated increase in fungal infections intensified the search for new, safer, and more efficacious agents to combat serious fungal infections [5]. Therefore, the continuing efforts to find out new antifungal agents are necessary and urgent. Most of the antimicrobial drugs used today are derived from natural product scaffolds [6].

Violet-pigmented bacteria, which have been described since the end of the $19^{\text {th }}$ century, are occasionally the causative agent of septicemia and sometimes cause fatal infection in human and animals. Bacteria, producing violet colonies due to the production of a non-diffusible pigment violacein, were classified as a redefined genus Chromobacterium [7].

Moreover, violacein recorded antifungal activity especially against chytrid fungus Batachochytrium dendrobatidis which is responsible for the worldwide decline in amphibian populations. Various biological and pharmacological properties of violacein have made it an attractive tool for medicinal and biotechnological research [8].

Chromobacterium violaceum is a Gram-negative bacteria found in water and soils in tropical and subtropical regions of the world. Due to its biotechnological potential, $C$. violaceum had its genome sequenced by the Brazillian National Genome Project. The most notable characteristic of $C$. violaceum is the production of the chemically well characterized pigment named violacein. Previous studies indicated antibiotic and antichagasic, antitumoral, and antileishmanial activities of violacein $[9,10,11]$.

Violacein producing bacteria with their striking purple hues have undoubtedly piqued by the condensation of two tryptophan molecules through the action of five proteins. The genes required for its production, vio ABCDE, and the regulatory mechanisms employed have been studied within a small number identifying the biological curiosity of scientists since the first discovery, the bisindole violacein is formed by violacein producing strain [12]. The pigmented molecule is of particular interest and understanding violacein's function and mechanism of action has relevance to those unmasking any of its commercial or therapeutic benefits.

Unfortunately, the production of violacein and its related derivatives is not easy and so, various groups are also seeking to improve the fermentative yields of violacein through genetic engineering and synthetic biology [13].

\section{Material and methods}

\subsection{Study Area and Water Sources}

This study was carried out in Owerri, Imo State, Nigeria. Owerri is the capital city of Imo State in Nigeria, set in the heart of Igbo land. It is bordered by two different domestic water sources: Otamiri river to the east and Nworie river to the south. Owerri has a tropical wet climate according to the koppen-Geger system. Rain falls for most months of the year with a brief dry season. Population of Owerri is 215038 people, latitude of 57500 (5450.00"N), longitude of 71167 (77'0.012"E) and Altitude of 152. Inadequate supply of portable drinking and domestic water in Owerri has led to the installation of underground and overhead water tanks. Also, borehole is installed from the supply of underground water [14].

Recreational use of water has important benefits to health and wellbeing of humans. Yet, there may also be adverse health effects associated with it, if the water is polluted or unsafe [15]. Common sources of contamination in swimming pool water quality include the water source, bather-derived chemicals [16]. These are evidence that $C$. violaceum can be isolated from domestic and recreational water sources.

\subsection{Isolation}

Three water samples were collected from different locations of the Otamiri river and five water samples from five different swimming pools of five hotels, and three from different boreholes using sterile amber bottles in Owerri Metropolis Area. The isolation C. violaceum was carried out by pour plate method on nutrient agar. The standard methods for the isolation and identification of bacteria as described by Dike-Ndudim et al., [14] was adopted in the analyses. $10 \mathrm{ml}$ of the sample was aseptically transferred into $250 \mathrm{ml}$ Erlenmeyer flask containing $22.5 \mathrm{ml}$ nutrient broth medium followed by incubation at $30^{\circ} \mathrm{C}$ for 24 hours. One loopful of bacterial culture was transferred onto nutrient agar 
plates and incubated for 24 hours at $30^{\circ} \mathrm{C}$. Serial sub-culturing was carried out until single bacterial colonies were obtained. The isolates from the contaminated water which appeared violet in colour were characterized to confirm the Chromobacterium violaceum.

\subsection{Extraction of Pigment}

Compound-violacein was extracted from C. violaceum and purified as described by Renee and Kendall, [17] with little modification. Ethanolic extraction of violacein was performed from a 48-hour broth culture.

\subsection{Susceptibility Test}

About four fungal colonies of similar morphology, at least $1 \mathrm{~mm}$ in diameter were picked from positive plates and added to $5 \mathrm{ml}$ of sterile saline solution $(0.85 \%)$ each, mixed for 15 seconds to allow hyphal fragments to fall out of the suspensions so that the supernatant containing the conidia could be collected. Inoculums were standardized with 0.5 tube of McFarland scale (105CFU/Ml) according to the method adopted by Anju et al., [4].

Antifungal agent (fluconazole) was purchased from Orchard pharmacy, Owerri and reconstituted according to manufacturer's instructions and serial two-fold dilutions (ranging from $50 \mu \mathrm{g} / \mathrm{ml}$ to $3.125 \mu \mathrm{g} / \mathrm{ml}$ ) were prepared with nutrient agar. Plates were incubated with $0.1 \mathrm{ml} \times 10^{5} \mathrm{CFU} / \mathrm{Ml}$ of test isolates. Control plates without antifungal agent were incubated with each set of drugs containing plates, aerobically for 24 hours at $37^{\circ} \mathrm{C}$ for C. albicans and 48 hours at $28^{\circ} \mathrm{C}$ for $A$. niger. The minimum inhibitory concentration (MIC) was defined as the lowest concentration of the antifungal agent the yielded no growth.

The MIC value of violacein was performed using the ager dilution method as described in M38-A2, [18]. The crude extracts were diluted by two-fold dilutions (ranging from $35 \mathrm{mg} / \mathrm{ml}$ to $2.19 \mathrm{mg} / \mathrm{ml}$, for extract from Otamiri river isolates and $35 \mathrm{mg} / \mathrm{ml}$ to $2.19 \mathrm{mg} / \mathrm{ml}$ for extract from recreational water isolates with nutrient agar and mixed vigorously to achieve these concentrations. Each of the prepared plates with the crude extracts were inoculated $0.1 \mathrm{ml}$ of the prepared inoculums. Positive control (medium with inoculums) and negative control (medium alone) was included in all experiments. The plates were incubated for 2 days at $28^{\circ} \mathrm{C}$ for $A$. niger and 24 hours at $37^{\circ} \mathrm{C}$ for $C$. albicans. The plates were observed for growth. Plates with growth were interpreted positive, while plates without growth were negative. The minimum inhibitory concentration was recorded as the lowest concentration of the extract that yielded no growth based on the method of Soares et al., [19] 'Susceptible breakpoint' is $<16 \mu \mathrm{g} / \mathrm{ml}$. "resistant breakpoint" is $>32 \mu \mathrm{g} / \mathrm{ml}$ according to Clinical Laboratory Standards Institute [18].

\section{Results}

The mean viable bacteria count from the water sources were generally high. Counts from domestic water source station 1 and 3 were highest having $\left(20.00 \times 10^{1} \mathrm{CFU} / \mathrm{ml}\right.$ and $\left.19.50 \times 10^{1} \mathrm{CFU} / \mathrm{ml}\right)$ respectively. Bacteria counts recorded for Otamiri water station 2 , recreational water source 1 and 3 were $14.50 \times 10^{1} \mathrm{CFU} / \mathrm{ml}, 11.00 \times 10^{1} \mathrm{CFU} / \mathrm{ml}$ and $11.50 \times$ $10^{1} \mathrm{CFU} / \mathrm{ml}$, respectively. For borehole 1,2 and 3, swimming pool 2, 4 and 5 , the counts were $0.00 \times 10^{1} \mathrm{CFU} / \mathrm{ml}$. Otamiri had more bacterial contamination than the swimming pool water samples as expressed by their viable bacterial counts. Fluconazole showed a very high MIC and Minimum Bactericidal Concentration (MBC) values for C. albicans $(25 \mu \mathrm{g} / \mathrm{ml}$ and $25 \mu \mathrm{g} / \mathrm{ml})$ and $A$. niger $(50 \mu \mathrm{g} / \mathrm{ml}$ and $50 \mu \mathrm{g} / \mathrm{ml})$ respectively.

Violacein extract on A. niger had a Minimum Inhibitory Concentration (MIC) 0f $8.75 \mathrm{mg} / \mathrm{ml}$ from both swimming pool and Otamiri water isolates. Violacein on C. albicans had MIC of $4.75 \mathrm{mg} / \mathrm{ml}$ and $4.375 \mathrm{mg} / \mathrm{ml}$ from recreational and domestic water isolates, respectively. The decrease in MIC of the extracts on fungi isolates shows a better effect of the extract against the fungi isolates.

There was a linear decrease in the MIC and MBC of the extracts to the organisms ranging from $A$. niger $(17.5 \mathrm{mg} / \mathrm{ml}$ and $35 \mathrm{mg} / \mathrm{ml})$ to $C$. albicans $(8.75 \mathrm{mg} / \mathrm{ml}$ and $17.5 \mathrm{mg} / \mathrm{ml})$.

\section{Discussion}

Evaluation of antibacterial and antifungal potentials of violacein extract from C. violaceum isolated from domestic and recreational water sources were carried out in this study. C. violaceum was isolated from domestic and recreational water sources. C. violaceum was present in the three water samples collected from three different sections of Otamiri river, which is in line with the report by Dike-Ndudim et al., [14]. No C. violaceum was isolated from the three borehole 
water samples, this contrast the same result by Dike-Ndudim et al., [14]; we assume that this could be as a result of low sample size of the borehole water investigated in this study.

From the five swimming pool water samples worked on, C. violaceum was isolated from only two samples. For identification of $C$. violaceum, our result agrees with the report of Ahmed et al., [20]. The isolate showed morphological characteristics as Gram negative rod similar to that isolated by Ahmed et al., [20]. Extraction of violacein from $C$. violaceum isolated from domestic and recreational water sources agrees with the study by Choi et al., [7]. In this study, the violacein extract obtained from the $C$. violaceum isolate was found to have similar effect with the one in previous study by Choi et al., [21] and Anju et al., [4]. In this study, the antifungal activity of violacein against $C$. albicans and $A$. niger, human pathogenic mycosis agent was evaluated including fluconazole as the standard drug. The violacein have high effect on both $C$. albicans and $A$. niger at concentrations of $8.75 \mu \mathrm{g} / \mathrm{ml}$ and $17.5 \mu \mathrm{g} / \mathrm{ml}$ respectively. This was in agreement with the study by Anju et al., [4]. In this work, violacein showed high effect against the selected fungi than the standard fluconazole, this suggested that violacein contributed much to the result explained by Anju et al., [4] where they evaluated the effect of azole drugs in synergy with violacein. The effect of violacein against fungi is reported here for the first time.

\section{Conclusion}

Several investigations have been made on the isolation of $C$. violaceum from water sources. In this study, $C$. violaceum was isolated from domestic and recreational water sources in Owerri.

Characterization and identification of the isolate match the result report by previous authors. For this study, the isolate shows violet pigmented colonies on nutrient agar plate. Extraction of violacein from the isolate was also recorded in this study.

Violacein, the major pigment produced by this bacterium was found to have antifungal effect on the selected fungi. Therefore, violacein can help to control the growth of fungi and thus prevent the occurrence of infectious fungemia and reduce the mortality rate caused by systemic candidiasis. It can also help to control diseases caused by Aspergillus spp such as pulmonary aspergillosis.

\section{Compliance with ethical standards}

\section{Acknowledgments}

Our sincere gratitude goes to our families as well as the staff and students of the Department of Medical Laboratory Science, Faculty of Health Sciences, Imo State University, Owerri, Nigeria for their immense support throughout the period of this work.

\section{Disclosure of conflict of interest}

There is no conflict of interest.

\section{References}

[1] Asticcioli S, Di Silverio A, Sacco L, Fusi I, Vincenti L, Romero E. Dermatophyte infections in patients attending a tertiary care hospital in Northern Italy. New Microbiology. 2008; 31: 543-548.

[2] Bitencourt TA, Komoto TT, Massaroto BG, MMiranda CES, Beleboni RO, Marins M. Trans-chalcone and quercetin down-regulate fatty acid synthase gene expression and reduce ergosterol content in the human pathogenic dermatophyte Trichophyton rubrum. BMC Complement of Alternative Medicine. 2013; 13: 229.

[3] Sydnor E. Hospital Epidemiology and Infection Control in Acute-Care Settings. Clinical Microbiology Reviews. $2011 ; 24(1): 141-173$.

[4] Anju S, Nishanth SK, Krishnakumar B, Dileep Kumar BS. Combination of Violacein and Azoles that leads to Enhanced Killing of Major Human Pathogenic Dermatophytic Fungi, Trichophyton rubrum. Front Cell Infection Microbiology. 2015; 5: 57.

[5] Mahmoud AG, Louis BR. Antifungal Agent: Mode of Action, Mechanism of Resistance, and Correlation of these Mechanisms with Bacterial Resistance. Clinical Microbiology Reviews. 1999; 24(4): 501-517. 
[6] Mishra BB, Tiwari VK. Natural products: an evolving role in futures drug discovery. European Journal of Medical Chemistry. 2011; 46: 4769-4807.

[7] Nelson D, Carlos FMM. Chromobacterium violaceum: A Review of Pharmacological and Industrial Perspectives. Critical Reviews in Microbiology. 2001; 27(3): 201-222.

[8] Wang H, Wang F, Zhua X, Yan Y, Yua X, Jiang P. Biosynthesis and Characterization of Violacein, Deoxyviolacein and Oxyviolacein in Heterologous Host, and their Antimicrobial Activities. Biochemical Engineer Journal. 2012; 67: 148-155.

[9] Duran N, Menck FM. Chromobacterium violaceum: A Review of Pharmacological and Industrial Perspective. Critical Review of Microbiology. 2011; 27: 201-222.

[10] Melo PD, Maria SS, Vidal BD, Haun M, Duran N. Violacein cytotoxicity and Induction of apoptosis in V79 cells. In vitro cellular and Developmental Biology - Animal. 2000; 36(8): 539-543.

[11] Leon LL, Miranda CC, de Souza AO, Duran N. Antibacterial activity of the violacein extracted from Chromobacterium violaceum. Journal of Antimicrobial Chemotherapy. 2001; 48(3): 449-450.

[12] Nelson D, Giselle ZJ, Carmen VF, Patricia M. Violacein: properties and biological activities. Biotechnology and Applied Biochemistry. 2007; 48: 127-133.

[13] Cazoto LL, Martins D, Ribeiro MG, Duran N, Nakazato G. Antibacterial activity of violacein against Staphylococcus aureus isolated from Bovine Mastitis. Journal of antibiotics. 2011; 64: 395-397.

[14] Dike-Ndudim JN, Dike DO, Ukogo I, Egbuobi RC, Nwigwe HC, Iwuala MOE. Bacteriological and Physico-chemical qualities of borehole water in Imo State. Microbes in the spotlight: Recent progress in the understanding of Beneficial and Harmful Microoorganisms. Foratex Research Center. Florida USA: Brown Walker Press Boca Raton. 2016; 37-39.

[15] Akhionbare SMO. The Environment. M C Computer Press, Nnewi, Nigeria. 2009; 193: 177.

[16] Jmaiff B, Lindsay K, Wang W, Vemula S, Jaeger BT. Sweetened swimming pools and hot tub. Environmental Science and Technology Letters. 2017; 4(4): 149.

[17] Reene SB, Kendall MG. Extraction of Violacein from Chromobacterium violaceum provides a new quantitative bioassay for N-acyl homoserine lactone autoinducers". Journal of Microbiological Method. 2000; 40: 47-55.

[18] Clinical and Laboratory Standards Institute. Performance standards for antimicrobial susceptibility testing; eighteenth informational supplement. CLSI document M100-18. Wayne, PA: Clinical and Laboratory Standards Institute. 2008.

[19] Soares LA, Gullo FP, Sardi JCO, Pitangui NS, Costa-Orlandi CB, Sngalli-Leite F. Anti-Trichhophyton activity of protocatechuates and their synergism with fluconazole. Evidence Based Complementary Alternative Medicine. 14: 1-9.

[20] Ahmad WA, Wan Ahmad WY, Zakaria ZA, Yusof ZN. Isolation of Pigment-producing Bacteria and Characterization of the extracted pigments, Application of Bacterial Pigment as Colorant. Springler briefs in Molecular Science. 2012.

[21] Choi S, Kim S, Lyuck S, Seung BM, Robert JM. High-level production of violacein by the newly isolated Duganella violaceinigra str. NI28 and its impact on Staphylococcus aureus. Scientific Reports. 2015; 5: 15598. 